\title{
STANDARDISATION OF FATWA IN MALAYSIA: ISSUES, CONCERNS AND EXPECTATIONS
}

\author{
Mohamed Azam Mohamed Adil*
}

\begin{abstract}
The establishment of the institution of fatwa can be traced back before the independence of Malaysia. In the beginning, a Mufti was placed under the respective Islamic Councils. To a certain extent, a Mufti was also a judge (kadi) and presided over cases in the Shari'ah courts. Legally, a Mufti's views are not considered as fatwas. Only fatwas issued by the respective States' Fatwa Committees are regarded as fatwas. A fatwa is binding upon Muslims of the state where it is issued after being consented to by the Sultan and later gazetted. The problem is that more often than not, conflicting fatwas at state and national levels do occur, and this has led to confusion and problems. This article attempts to analyse the problems surrounding the conflicting fatwas. It suggests that the standardisation of fatwas at state and federal levels could be done by requesting the respective States' Fatwa Committees to abide by the fatwas issued by the National Fatwa Committee. It is also suggested that fatwas issued by the respective States' Fatwa Committees should be brought up to the National Fatwa Council for standardisation. It is also suggested that a Grand Mufti should be appointed on rotational basis like the selection of the Yang Di Pertuan Agong, after being consented to by the Council of Rulers. However, the position of Gand Mufti will not supersede the position of the respective States' Muftis.
\end{abstract}

\section{Introduction}

The Ninth Schedule of the Federal Constitution provides powers and jurisdictions to the respective States to manage and administer Islamic affairs. This is in line with the position of the respective Sultans as heads of the religion of Islam except in the states of Penang, Melaka, Sabah, Sarawak and the Federal Territories. ${ }^{1}$

The Yang Dipertuan Agong (YDA) and respective Sultans hold the highest position in matters relating to Islamic affairs. The Islamic Religious Council is established in every state. It has a role to facilitate and to advise the YDA and the respective Sultans in matters relating to Islam. The importance of the Religious Council can be traced back to the establishment of the Religious Council of Kelantan in $1915 .^{2}$ The role of the Religious Council is to ensure the welfare of Muslims from the spiritual, social, educational and economical aspects. ${ }^{3}$ To ensure that the Islamic Councils are effective and efficient, the state governments separated the administration of the Islamic Councils from that of the Islamic Departments / Shari'ah Courts / Departments of Mufti. For the purpose of this 
segregation, all states' enactments have a specific provision for the appointment of a Mufti and a Deputy Mufti (not in every state) to administer the fatwa affairs in the respective states. ${ }^{4}$

\section{The Legal-Institutional Framework of Fatwa}

\section{(i) The Establishment of Fatwa Committee}

The respective States' Islamic Administration Laws have empowered the states to establish a Fatwa Committee to assist the Department of Mufti in issuing fatwas. ${ }^{5}$ The Committee has several names, among others:

- Islamic Ruling Committee (Jawatankuasa Perundingan Hukum Syara')

- Shari'ah Committee (Jawatankuasa Syariah).

- Fatwa Council (Majlis Fatwa).

- Fatwa Board/Body (Lembaga Fatwa).

- Fatwa Committee (Lujnah/Jawatankuasa Fatwa).

- Council of Ulama (Jama'ah Ulama). ${ }^{6}$

The total of the Fatwa Committee members differs from one state to another. Normally it consists of 5-17 members. ${ }^{7}$ For example, in Selangor, Administration of the Religion of Islam (State of Selangor) Enactment 2003 provides:

"There shall be a committee by the name of Fatwa Committee that consists of:

a. Mufti-Chairman;

b. Deputy Mufti;

c. State Legal Advisor;

d. Two members from the Islamic Council (Majlis);

e. An officer from the Selangor Islamic Department who is an expert in Islamic rulings appointed by the Islamic Council (Majlis);

f. No fewer than two members and no more than seven members who are fit to be appointed by the Islamic Council (Majlis); and

g. An officer from the Department of Mufti to act as the secretary."

All members of the Committee including Muftis and Deputy Muftis are appointed by the respective Sultans and YDA. The National Fatwa Council is set up by the Council of Rulers (MRR) in accordance with the National Rulings of Islamic Affairs amended in 1971, 1973, 1976 and 1980. ${ }^{8}$

In carrying out its duties and roles, the National Fatwa Council has endorsed two approaches: National Fatwa Council Meeting under the order of Council of Rulers (MRR); and National Fatwa Committee Discourse (Muzakarah) in which this meeting takes place occasionally without order from the Council of Rulers (MRR). ${ }^{9}$ 
Membership of the National Fatwa Council should consist of the following:

a. Chairman;

b. Respective States' Muftis;

c. Five members appointed by the Council of Rulers (MRR); and

d. A member who is a Muslim from the legal or judicial profession appointed by the Council of Rulers (MRR). ${ }^{10}$

Except the Chairman and respective states' Muftis, the other candidates must first obtain consent from the Prime Minister before submitting the names to the Council of Rulers (MRR). Such appointment is valid for three years, and can be extended after the term expires should the authority think to do so. Without prejudice, the members, at any time, can tender a resignation without giving any reasons. ${ }^{11}$

\section{(ii) The Role of Mufti and Fatwa Committee}

The States' Fatwa Committees assist and advise the respective Sultans over matters relating to Islamic rulings. The Mufti shall advise the Sultan in respect of all matters of Islamic law. He shall be the chief authority in the State after the Sultan, except where otherwise provided in the Enactment. ${ }^{12}$ The State's Fatwa Committee can act on its own or upon the request from the public, which should be addressed to the Mufti to seek a fatwa over a disputed matter. ${ }^{13}$ A Mufti could issue a fatwa or give his view or evidence in case requested by either the Civil Court or the Shari'ah Court. But the judge is not obliged to accept the view given by the Mufti as he is deemed competent to handle a case brought before him. However, a Mufti cannot be summoned to be present before a judge. ${ }^{14}$

In Isa Abdul Rahman and Others $v$ the Penang Islamic Council,${ }^{15}$ the view of Mufti and the gazetted fatwa were referred to by the Court when the plaintiff who was the next-of-kin of the owner wakaf property objected to the plan by the Penang Islamic Council to demolish Masjid Jamek Haji Abdul Wahab and to erect a new five-floor building which places Bank Islam (floors 1-3) and mosque (floors 4-5) on the wakaf land.

The High Court turned down the injunction applied by the plaintiff and requested the Penang Islamic Council not to continue with the plan until a new fatwa is issued on this matter. Apparently, there were two conflicting fatwas: the former fatwa was meant that the wakaf land was for the purpose of building a mosque; and the latter fatwa giving a nod for the Penang Islamic Council to demolish the mosque and to erect a new building but with condition to reserve two floors for mosque purposes.

What was interesting about this case was that the provisions in section 36 (4-5) of the Penang Administration of Islamic Law No. 7/1993 provide that all written fatwas must be recognised by all courts in the State of Penang, and any written document made by the Mufti is considered as fatwa. 
Judge Abdul Hamid Mohamad who presided over the case did not accept these provisions as he believed that the "courts" referred to here were the Shari'ah courts, and not the civil courts. As a result, laws passed by the Penang State Assembly do not take away the powers and jurisdiction of the civil courts as enshrined by the Federal Constitution.

Apparently, a fatwa that is in accordance with written laws is referred to by the civil court. In Re Dato Bentara Luar (Deceased), Haji Yahya Yusoff \& Others v Hassan Othman \& Others, ${ }^{16}$ the High Court of Johor made reference to the fatwa issued by the Mufti of Johor over a specific wakaf (wakaf khas). It was decided that such wakaf was valid under Islamic law as provided in Section 11 of Prohibition Wakaf Enactment of Johor, 1911 and Section 41 Administration of the Religion of Islam Enactment of Johor, 1978.

Interestingly, at the Supreme Court, Salleh Abas (CJ) ruled out that the court should neither accept nor decline the fatwa. But since the judges were not competent in Islamic law and the fatwa was in line with other scholars' writings, they could accept such fatwa.

In Hajjah Halimatussaadiah v Public Service Commission, Malaysia \& Anor, ${ }^{17}$ the appellant, who was a clerk at the Perak Legal Advisor's Office, was given a warning followed by a show-cause letter because she did not conform to the General Order that prohibits women from covering their face during office hours. She argued that her understanding from verse 24 of Surah al-Nur was that covering her face except the eyes was obligatory. Indeed, such attire could protect her dignity. She also argued that such practice was guaranteed in Article 11(1) of the Federal Constitution.

After considering the fatwa issued by the Federal Territories' Mufti, the Court held that Islam neither make it compulsory nor encourages such veil. It was also held that freedom of religion as provided in Article 11(1) of the Federal Constitution was not absolute as this Article must read together with Article 11(5) that restricts religious freedom on the ground of public peace, public health and morality. Hence, such prohibition regulated in the General Order never takes her constitutional right in professing and practicing her religion.

In another case, Dalip Kaur v Bukit Mertajam's Police Officer and Others, ${ }^{18}$ the appellant made an appeal before the Supreme Court seeking a declaration that his late son was non-Muslim at his last breath and therefore she could claim the body. The Kedah Fatwa Committee held that his late son was a Muslim at his death because there was evidence that he had converted to Islam, and no declaration had been made by any Shari'ah Court otherwise. The Supreme Court also accepted the fatwa issued by the Kedah Fatwa Committee for the following reasons: 
a. Whereby a Muslim who has made a deed-poll declaration that he is no longer practicing the religion of Islam is indeed an apostate.

b. That a Muslim who prays in the Sikh temple and seeking Sikh prayers is indeed an apostate.

c. That a Muslim who has converted to Sikhism is indeed an apostate. However, such rule can only be made by the Shari'ah court. Unless and until such declaration is made, that person is considered as Muslim.

d. That a Muslim who consumes pork is still regarded as Muslim.

e. That a male who converted to Islam but did not circumcise is considered as Muslim.

Hence, the Kedah Fatwa Committee held that the appellant's son was a Muslim at his death because there was evidence that he recited the testimonial (shahadah) and became Muslim. Furthermore, there was no declaration made by any Shari'ah courts that showed he was not a Muslim upon his death.

\section{(iii) Issuance and Gazetting of Fatwas}

Legally, only a gazetted fatwa is binding. A Mufti's view cannot be binding even if it is done before a judge. With an exception in Penang, a written statement by the Mufti is regarded as fatwa by the Court. ${ }^{19}$

In most practices in the states of Malaysia, the process of fatwa starts with an inquiry to the Islamic Council (Majlis). The inquiry is then passed over to the Mufti, Chairman of the Fatwa Committee. Occasionally, it is addressed directly to the Mufti. The Mufti, as Chairman of the Fatwa Committee, upon receiving the request/inquiry will prepare a concept paper. ${ }^{20}$

On many occasions, a research committee is set up to carry out thorough research. The result of the research will then be discussed before the members of the State Fatwa Committee. Later, the office of the Department of Mufti will prepare a fatwa draft and refer it to the State Legal Advisor for scrutiny. The draft will be discussed and debated in the State Fatwa Committee and later brought to the Islamic Council meeting chaired by the Chairman. Once the fatwa is accepted, it will then be brought up to the Sultan for consent and later gazetted. The gazetted fatwa is binding upon all Muslims in the state concern and should be recognised by the court at that state. ${ }^{21}$ 
The State Fatwa Committee Structure:

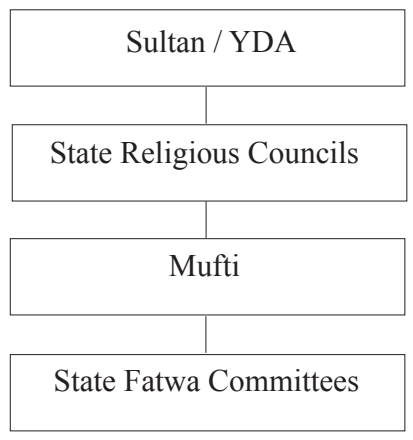

As for the state of Selangor, Section 48 of Administration of the Religion of Islam (State of Selangor) Enactment 2003 provides the procedure for issuing a fatwa. A Mufti can request research to be carried out before the State Fatwa Committee sits for a meeting. The research committee is expected to prepare a concept/working paper. The Mufti will call the State Fatwa Committee for a meeting to discuss the proposed fatwa.

After an in-depth discussion and debate in the meeting, the Mufti will then pass the proposed fatwa to the Islamic Council (Majlis). The Islamic Council (Majlis), after scrutiny of the proposed fatwa could suggest the proposed fatwa to be brought up to the Sultan for consent and later gazetted. The proposed fatwa should be written clearly under sub-section (4) together with details and comments. Once the fatwa is approved by the Sultan, the Islamic Council (Majlis) should inform the State Government before the fatwa is published in the gazette. A fatwa published in the gazette shall be followed by a statement that the fatwa is made under this section.

All fatwas shall be published in Bahasa Melayu in Romanised transcript but the Bahasa Melayu version can also be made public. Statements made by the State Fatwa Committee could not be regarded as fatwa unless it is published in the gazette under sub-section (6).

From the technical point, a proposed fatwa must be scrutinised by the Selangor State Legal Advisor before bringing it up to the Sultan. Once it is approved by the Sultan, the fatwa can be for gazetted.22 


\section{iv) The Position of National Fatwa}

At the Federal level, a fatwa is issued by the National Fatwa Committee or National Fatwa Discourse meetings, which take place under the National Fatwa Council, headed by a Chairman. Usually, the National Fatwa Discourse (Muzakarah) meets regularly because it does not require an order from the Council of Rulers (MRR). All State Muftis are automatically members of the National Fatwa Council including those who are from the judicial and legal service who are appointed by the Council of Rulers (MRR). ${ }^{23}$

The National Fatwa Council secretariat is placed under the Department of Islamic Development Malaysia (JAKIM). ${ }^{24} \mathrm{~A}$ fatwa can be decided either unanimously or by a majority vote of two-thirds of the members excluding the Chairman. Unfortunately, a fatwa decided by the National Fatwa Council is not binding from the legal perspective. In fact it is only binding within the states if the states adopt and enforce the fatwa..$^{25}$

Normally, a fatwa issued at the Federal level will be forwarded to the respective States' Fatwa Committees for consideration. If accepted, the fatwa will be brought up to the next process for gazetting purposes. Apparently, the National Fatwa Council is a "body of discussion" to decide on a fatwa involving national interest. It does not bind the states including the Federal Territories. ${ }^{26}$

\section{The Controversy over Conflicts of Fatwas}

\section{(i) Conflicts between Fatwas issued by the National Fatwa Council and the} Respective States' Fatwa Committees

Conflicts between fatwas can be traced in the Emotional Spiritual Quotient (ESQ) Leadership training module. The Federal Territories Fatwa Committee in its meeting on 27 August 2009 simply banned ESQ fearing that it could harm the faith and the religion of Islam. ${ }^{27}$ A similar stand was also taken in Perlis by its Fatwa Committee. However, the National Fatwa Council in its meeting on 16 June 2010 gave a green light for ESQ organisations to continue their activities with conditions that they must appoint Shari'ah Advisors to monitor their activities. This stand was also taken by the Pahang and Penang Fatwa Committee which have endorsed the ESQ organisations. ${ }^{28}$

Another example is the question of investment in Amanah Saham Bumiputra (ASB)/Amanah Saham Nasional (ASN). The States of Selangor and Penang have prohibited it because, apparently, ASB/ASN investment is involved in interest (riba) transactions which are non-Shari'ah compliant. But there was confusion in the Penang fatwa issued on 30 August 1983 which allowed Muslims to perform hajj using money from the ASN. ${ }^{29}$ 
The National Fatwa Council in its meeting on 1-3 February 2008; the Federal Territories Fatwa Committee in its meeting on 27 May 2008; and the Kelantan Fatwa Committee in its meeting on 27 December 2009 have opined that putting an investment in ASB/ASN is permissible mainly because it is the only institution that is available to Malay-Muslim investors for purpose of earning profits considering the low and poor economic background of the majority Malays. Another point made was that if PNB, which is the agent of ASB/ASN pulls out its share from Maybank which is considered the largest bank in the Asia Pacific, it could easily harm the economy of the Malays who are Muslims. What is important is that, PNB does not invest in the provision of gambling services and the production of liquor. In its investments, PNB has managed to invest $70 \%$ of its investment activities in Shari'ah compliant ways. The remaining 30\% investment in Maybank which is non-Shari'ah compliant is strictly monitored by the Shari'ah Advisors appointed by PNB under the Special Project. ${ }^{30}$

Indeed, according to the National Fatwa Committee, the schools of Hanafi, Maliki, Shafi'ie and Hanbali are of the views that Muslims are permitted to invest in companies that invest in both halal and haram activities under certain circumstances based on public interest (maslahah ammah). In sum, the Committee is of the view that protecting the interest (maslahah) of the Muslims is more important than avoiding harm (mafsadah) and that this should be the main criteria in this regard. ${ }^{31}$

Another example is the prohibition of smoking. Some states have made it abominable (makruh) while others have regarded it as forbidden (haram). The states of Kedah and Selangor have made it forbidden (haram), while Pahang banned smoking in places of worships. At the Federal level, the National Fatwa Council has banned smoking completely. ${ }^{32}$ In reality, the respected States' Fatwa Committee should adopt the National Fatwa Council's fatwas. For example, Section 52(1) the Selangor Islamic Administration, 2003 provides:

"The Fatwa Committee should adopt the advice and recommendations made by the National Fatwa Council in matters that have been consented by the Council of Rulers (MRR) as enshrined in Article 38 2(b) of the Federal Constitution."

\section{(ii) Conflicts of Fatwas between the Respective States' Fatwa Committee}

Conflict among fatwas issued by different states is quite apparent in some cases. One example is zakat on income. The states of Selangor and Perak have a different stand in making zakat on income obligatory. The Selangor Fatwa Committee has gazetted a fatwa that made it obligatory for Muslims in Selangor to pay zakat on income since 9 May 2001. What is interesting about this fatwa is that such 
zakat must be handed over to Lembaga Zakat Selangor (LZS), the collector of zakat for the Selangor Religious Council. The payment of zakat on income can be made through salary deduction despite the fact that this method of collection does not meet the requirement of nisab and haul according to the majority of the schools of Islamic law. The approach taken by LZS is basically based on ta'jil al-zakat (payment of zakat before the haul) but it does not meet the requirement that the payment of income/salary zakat can only be made if it meets the nisab..$^{33}$ A similar approach was also taken by the Federal Territories' Religious Council (MAWIP) requirements of ta'jil where a fatwa gazetted on 29 April 1999 has made it obligatory upon Muslims in the Federal Territories to pay zakat on any income including salary, allowances and bonus. ${ }^{34}$

The National Fatwa Council did not make it compulsory for Muslims in the Federal Territories to pay income zakat but made it optional (9 December 1992). However, on 22 June 1997 it changed its fatwa by making it compulsory for Muslims who were earning a steady income. In its meeting on 7 May 2003, the National Fatwa Committee had issued the calculation for the income zakat payment which was based on $2.5 \%$ from nisab in one-year hijrah (haul) period. ${ }^{35}$

In contrast, the Perak Fatwa Committee is against the stand taken by Selangor, Federal Territories and National Fatwa Council in requiring Muslims to pay income (salary) zakat simply because income/salary will only be taxable when it reaches the one-year hijrah period. In its meeting on 7 March 2013, the Perak Fatwa Committee had endorsed one statement:

"That zakat on income/salary is only obligatory when it reaches the nisab and haul as agreed by the majority schools. Hence zakat on income/salary is not compulsory". ${ }^{36}$

\section{Will Standardisation of Fatwas Resolve the Conflicts?}

Standardisation of fatwas is often discussed by many parties. This is because conflicting fatwas have caused confusion and problems in society. In general, conflicting fatwas can occur due to several reasons, among others, conflict of fatwas between issuing institutions of fatwa. This can be seen in different fatwas issued by the National Fatwa Council and the respective States' Fatwa Committee. Similarly, different fatwas are issued in different states. Another conflict between fatwas involves private fatwas. This occurs as a result of a conflict between fatwas issued by institutions and fatwas issued by private; there is also conflict between some private fatwas and other private fatwas. ${ }^{37}$

Datuk Seri (now Tun) Abdullah Ahmad Badawi, then Vice-President of the United Malays National Organisation (UMNO), the dominant party in the ruling 
Barisan Nasional coalition in Malaysia, once commented:

More often than not, we hear of contradictory views or rulings by Mufti in matters pertaining to zakat fitrah and others. Therefore, it's important to have a standardised fatwa so that people will no longer be confused. ${ }^{38}$

Apparently, all Muftis have endorsed the proposal. Based on our research, ${ }^{39} 13$ Muftis (93\%) agreed that the activities of all fatwa bodies should be coordinated and standardised. As for the officers, 10 of them (71\%) agreed that the activities on the respective fatwa bodies should be coordinated and standardised. Three officers $(21 \%)$ did not agree and one officer $(7 \%)$ did not come out with any comments. Those who disagreed gave the following reasons for their views:

i) Fatwa is a state matter as provided in the state constitution.

ii) Powers relating to Islam are under the respective Sultans and states' government jurisdictions.

iii) The background and environment vary from one state to another.

iv) Diversity of opinions is good practice. ${ }^{40}$

Nevertheless, the outcome of our research shows that many high-ranking religious officers did not agree with the standardisation of fatwas. Among reasons given are:

i) It is provided in every state's enactment that a Sultan shall appoint a Mufti to advise him in matters relating to Islam.

ii) The appointment of Mufti within the respective states is effective as he is the expert in matters pertaining to Islamic law, which falls under state jurisdiction. This is very different from Egypt and Saudi Arabia.

iii) The establishment of Mufti in every state could be an impetus for the states to set up the Council of Figh (Majma' al-Fiqhi) for collective fatwas. ${ }^{41}$

However, there are views that support the coordination of fatwa bodies because too many Muftis will lead to inefficiency in the issuance of fatwas. To a certain extent, there should not be a Mufti appointed at a state level. Instead, there should be coordination among all fatwa issuing bodies so that they could produce standard fatwas for the entire nation taking into account the public interest. However, if the fatwa meets the local needs, for example, by determining the rate of zakat fitrah, it should not be standardised. ${ }^{42}$

As for the public, 95\% responded that a standard fatwa is important to ensure that no misunderstanding of the fatwa takes place. Some suggested the appointment of Grand Mufti. This was proposed in Parliament in 17 Sept. 2003. The issue was originally raised by Tuan Haji Mo'min Abdul Aziz, Chairman, Melaka Islamic Religious Committee in 1996. It was then re-suggested by 
(Dato') Dr. Syed Ali Tawfik al-Attas, the Former Director-General of IKIM in December 2006. However, Tan Sri Dato' Seri Harussani Zakaria, the Mufti of Perak stood against the idea. Dato' Seri Najib Tun Razak (the then Deputy Prime Minister) and Datuk Seri Dr. Ahmad Zahid Hamidi (the then Minister in the Prime Minister's Department) were also of the view that the proposal to appoint a Grand Mufti was not suitable. ${ }^{43}$ The reasons for objections include:

i) The appointment of Mufti is under the privilege of the respective Sultans (YDA for non-Sultans' states).

ii) Sultans are not willing to lose their small powers given by the Federal Constitution.

iii) The suggestion seems contrary to Article 74 and Ninth Schedule of the Federal Constitution. ${ }^{44}$

However, the standardisation of fatwa bodies could be possible if there is a political will. ${ }^{45}$

With effect from 2 Sept. 1997, there was an agreement by the respective Muftis that they should refer to the National Fatwa Council before gazetting a fatwa. ${ }^{46}$ But does this take place? It was revealed that $36 \%$ of Muftis in Malaysia do not agree on the establishment of National Fatwa Council. This is because the Council has no power and cannot compete with the States' Fatwa Committee. Fatwa issued by the National Fatwa Council is not binding at all. What has been decided at the National Fatwa Council can be challenged by the State Fatwa Committees. The National Fatwa cannot be gazetted and as a result it has to be brought to the respective States' Fatwa Committee for consideration and later gazetted, if they wish to do so. ${ }^{47}$

In order to introduce a standard fatwa, a proposal to set up a Federal Darul Ifta' was turned down by the Council of Rulers (MRR). As a result, the secretariat for the National Fatwa Council has been streamlined. On 2 January 2009, the Division of Management and Development of Fatwa was introduced at JAKIM. One of the objectives of the setup was to undertake in-depth study before a fatwa is issued. This does not mean that such study was not carried out before. ${ }^{48}$

It is quite difficult to come out with a common fatwa in Malaysia as there are 14 Muftis with different backgrounds. Furthermore, there are 14 States' Fatwa Committee with differing views. More often, the State Fatwa Committees are reluctant to accept fatwas issued by the National Fatwa Council. They have two simple reasons:

a. That the powers and jurisdictions of the religion of Islam are within the exclusive rights of states and Sultans; and

b. That powers and jurisdictions are clearly provided in Ninth Schedule, List II State List and Article 74(2) of the Federal Constitution. 
The powers and jurisdiction of Islam are under the purview of the respective states have made it difficult to standardise fatwas in Malaysia. Standardising fatwas across the nation is not impossible since the National Fatwa Council is set up to assist on the standardisation. The role of the National Fatwa Council seems limited but one could find that this Council could advise to the Council of Rulers, State Governments or States' Islamic Councils to look at matters concerning the Islamic law or Islamic administration and the religious studies. The composition of Fatwa Committee is also insufficient. Very few of the members of the Fatwa Committee are highly educated. Out of 129 of members of fatwa committee throughout the nation, only 27 are from academics. Another factor that contributes to the conflicting fatwas is the difference fatwa methodologies applicable in Malaysia. The state of Perlis which based on Ahli Sunnah wal Jama 'ah's teaching, does not practise the Shafi'i's school which is dominant across Malaysia. ${ }^{49}$

Similarly, some Muftis issue conflicting fatwas on controversial issues in the mainstream media, which has led to confusion among the public. What is worse is that an "open debate" on a particular issue does not solve any problem. In fact, debates should take place in designated institution like the National Fatwa Council or during the National Fatwa Committee Discourse (Muzakarah) meetings.

Actually, there was an attempt to standardise the process of fatwa in Malaysia. For example, an informal body called the Council of Muftis Malaysia (Majlis Mufti-mufti Se-Malaysia) was established in 1998. The council comprises all state Muftis. It serves as a platform for discussion between them in matters of religion more freely. For example, the first decision by the Council was to seek a reduction of Bollywood movies on television in Malaysia. In response, the government adopted the view of the Council and subsequently made a study of the decision..$^{50}$

\section{Conclusions}

From the above discussion, it can be said that conflicts between fatwas do occur in Malaysia because every State Fatwa Committee has a power to issue fatwa. As a result, a resolution is required so that fatwas issued by the National Fatwa Council would be adopted in the respective states.

- It is suggested that fatwas issued by the respective States' Fatwa Committee should be brought up to the National Fatwa Council for standardisation.

- To appoint a Grand Mufti who is highly knowledgeable with Shari'ah background. The present Chairman of the National Fatwa Council has no Shari'ah background and only functions as a spokesperson. The Grand Mufti must be senior by age. This criterion is to include the State Muftis. 
- The appointment of Grand Mufti is on a rotation basis like the selection of YDA. It must be approved by the Council of Rulers (MRR). The position of Grand Mufti will not supersede the position of respective States' Muftis.

- Fatwas issued by the Grand Mufti are binding. The respective States' Muftis must accept the fatwas issued by the Grand Mufti so that they are not in conflict. This could be done by amending the Ninth Schedule, List II - State List and Article 74 of the Federal Constitution.

- The States' Muftis are prohibited from issuing controversial statements. Only the Grand Mufti is authorised to issue any statement after discussing the matter at the National Fatwa Council.

- As for remuneration, the Grand Mufti should be at par to Turus III. As for States' Muftis, they should be remunerated at par to JUSA A.

\section{Notes}

* Mohamed Azam Mohamed Adil is Associate Professor and Deputy CEO, International Institute of Advanced Islamic Studies (IAIS) Malaysia (Email: mazamadil@iais.org.my).

1. Article 42 (10) of the Federal Constitution.

2. Abdullah Alwi Hassan, The Administration of Islamic Law in Kelantan, Dewan Bahasa \& Pustaka, Kuala Lumpur, 1996, pp. 69-70.

3. Section 7, Administration of the Religion of Islam (State of Selangor) Enactment 2003.

4. For example, Section 44 of the Administration of the Religion of Islam (State of Selangor) Enactment 2003.

5. Farid Sufian Shuaib, Tajul Aris Ahmad Bustami \& Mohd Hisham Mohd Kaal, Administration of Islamic Law in Malaysia - Text and Material, Malayan Law Journal, 2001, pp. 266-70.

6. Suwaid Tapa, Perundangan dan Penguatkuasaan Fatwa in Ahmad Hidayat Buang, Fatwa di Malaysia, Jabatan Syariah dan Undang-undang, Akademi Pengajian Islam, Universiti Malaya, 2004, pp. 26-7.

7. See respective States's Administration of the Religion of Islam. Johor: 5; Kedah: 9; Kelantan: 17; Melaka: 8; Negeri Sembilan: 7; Pahang: 10; Perak: 9; Perlis: 7; Penang: 10; Sabah: 6; Sarawak: 7; Selangor: 10; Terengganu: 10; and Federal Territories: 9; see Mohamed Azam Mohamed Adil, Organisasi dan Pentadbiran Jabatan Mufti in Ahmad Hidayat Buang, Fatwa di Malaysia, Jabatan Syariah dan Undang-undang, Akademi Pengajian Islam, Universiti Malaya, 2004, p. 51.

8. Suwaid Tapa, Perundangan dan Penguatkuasaan Fatwa. supra, pp. 26-7.

9. Mohamed Azam Mohamed Adil, "Penyelarsan Fatwa:Isu, Masalah dan Harapan," Jurnal Hukum, Jld.38. Bhg 1, Rabiulakhirn1435H/February 2014M, pp. 2-3.

10. Section 14 of the Regulation of National Council of the Religion of Islamic Affairs as amended by the Council of Rulers (MRR) $117^{\text {th }}$ meeting, 17 February 1980.

11. Section 13 of the Regulation of National Council of the Religion of Islamic Affairs as amended by the Council of Rulers (MRR) $117^{\text {th }}$ meeting, 17 February 
1980.

12. Section 45, Administration of the Religion of Islam (State of Selangor) Enactment 2003; see also Farid Sufian Shuaib, Powers and Jurisdiction of Syariah Courts in Malaysia, Malayan Law Journal, 2003, pp. 43-7.

13. Section 47, Administration of the Religion of Islam (State of Selangor) Enactment 2003.

14. For example see Section 53, Administration of the Religion of Islam (State of Selangor) Enactment 2003; Mohamed Azam Mohamed Adil, "Penyelarasan Fatwa:Isu, Masalah dan Harapan," supra, p. 3; Suwaid Tapa, Perundangan dan Penguatkuasaan Fatwa, supra, p. 29.

15. [1997] 5 Jurnal Syariah (1) 125.

16. [1981] 2 MLJ 352.

17. [1992] 1 MLJ 513.

18. [1992] 1 MLJ 1.

19. Suwaid Tapa, Perundangan dan Penguatkuasaan Fatwa, supra, p. 34; Mohamed Azam Mohamed Adil, "Penyelarasan Fatwa: Isu, Masalah dan Harapan," supra, pp. 5-6.

20. Ibid.

21. Ibid.

22. Section 48 of Administration of the Religion of Islam (State of Selangor) Enactment 2003.

23. Suwaid Tapa, Perundangan dan Penguatkuasaan Fatwa, supra, pp. 36-37; Farid Sufian Shuaib, Tajul Aris Ahmad Bustami \& Mohd Hisham Mohd Kamal, Administration of Islamic Law in Malaysia - Text and Material, supra, pp. 27182.

24. In practice, the Director-General of JAKIM is the Secretary of National Fatwa Council.

25. Suwaid Tapa, Perundangan dan Penguatkuasaan Fatwa, supra, pp. 36-7.

26. Ibid.

27. www.e-fatwa.gov.my; Muhammad Ikhlas Roslee, "Konflik Fatwa di Malaysia: Satu Kajian Awal", Jurnal Fiqh, supra, pp. 38-39; Mohamed Azam Mohamed Adil, Penyelarasan Fatwa: Isu, Masalah dan Harapan, supra, pp. 11-2.

28. Ibid.

29. Mohamed Azam Mohamed Adil, Penyelarasan Fatwa: Isu, Masalah dan Harapan, supra, pp. 12-3.

30. Mohamed Azam Mohamed Adil, "ASB, ASN Berlandaskan Maqasid Syariah Pelaburan Diharuskan Bagi Menegakkan Keadilan, Basmi Kemiskinan," Berita Harian, 4 Mac 2014, p. 33.

31. http://www.e-fatwa.gov.my/fatwa-kebangsaan/pelaburan-dalam-asn-asb-danseumpamanya.

32. Mohamed Azam Mohamed Adil, Pengaruh Adat Tempatan dalam Menentukan Fatwa di Malaysia in Ahmad Hidayat Buang, Fatwa di Malaysia, Jabatan Syariah dan Undang-undang, Akademi Pengajian Islam, Universiti Malaya, Kuala Lumpur, 2004, pp. 202-23.

33. Suryani Masnan, Kaedah Pembayaran Zakat Pendapatan Melalui Skim Potongan Gaji Oleh Lembaga Zakat Selangor, Dissertation, Master of Shari'ah, University of Malaya, 2012, pp. 146-51; 203. 
34. http://www.e-fatwa.gov.my/fatwa-negeri/zakat-penggajian-2.

35. http://www.e-fatwa.gov.my/fatwa-kebangsaan/zakat-gaji-beserta-kadarnya.

36. http://www.e-fatwa.gov.my/fatwa-negeri/zakat-atas-gaji-pendapatan-0.

37. Muhammad Ikhlas Rosele, Luqman $\mathrm{Hj}$ Abdullah, Paizah $\mathrm{Hj}$ Ismail \& Mohd Anuar Ramli, "Konflik Fatwa di Malaysia: Satu Kajian Awal", Jurnal Fiqh, No.10 (2013), pp. 37-8.

38. NST, 30 August 1997.

39. A comprehensive research Analysis of Contemporary Fatwas in Malaysia under IRPA RMK7 University of Malaya was carried out from 1997-2000 led by Ahmad Hidayat Buang. Other members were: Mohamed Azam Mohamed Adil, Suwaid Tapa, Raihanah Abdullah and Khadijah Hambali.

40. Ahmad Hidayat Buang et.al, Laporan Projek Penganalisaan Fatwa-fatwa Semasa di Malaysia, Jabatan Syariah dan Undang-undang, Akademi Pengajian Islam, Universiti Malaya, 2000; see also Mohamed Azam Mohamed Adil, Organisasi dan Pentadbiran Jabatan Mufti, supra, pp. 58-9.

41. Ahmad Hidayat Buang et.al, Laporan Projek Penganalisaan Fatwa-fatwa Semasa di Malaysia, supra; Mohamed Azam Mohamed Adil, Organisasi dan Pentadbiran Jabatan Mufti, supra, pp. 59-60.

42. Ahmad Hidayat Buang et.al, Report Analysis of Contemporary Fatwas in Malaysia, supra; Mohamed Azam Mohamed Adil, Organisasi dan Pentadbiran Jabatan Mufti, supra, p. 60.

43. Mohamed Azam Mohamed Adil, Organisasi dan Pentadbiran Jabatan Mufti, supra, pp. 58-61.

44. Ibid, pp. 58-61.

45. Ibid, p. 61.

46. Ibid. p. 61.

47. For example, see Section 48 Issuance of fatwa, Selangor Islamic Administration Enactment, 2003.

48. Mohamed Azam Mohamed Adil, Penyelarasan Fatwa: Isu, Masalah dan Harapan, supra, p. 11.

49. Mohamed Azam Mohamed Adil, Organisasi dan Jabatan Mufti, supra, p. 51.

50. Ahmad Hidayat Buang, Fatwa di Malaysia, supra, pp. 65-6.

\section{References}

1. Ahmad Hidayat Buang, Fatwa di Malaysia, Jabatan Syariah dan Undang-undang Akademi Pengajian Islam, Universiti Malaya, Kuala Lumpur, 2004.

2. Ahamad Hidayat Buang, Analisis Fatwa-fatwa Syariah in Ahmad Hidayat Buang, Fatwa di Malaysia, Jabatan Syariah dan Undang-undang, Akademi Pengajian Islam, Universiti Malaya, Kuala Lumpur, 2004.

3. Ahmad Hidayat Buang et.al, Laporan Projek Penganalisaan Fatwa-fatwa Semasa di Malaysia, Jabatan Syariah dan Undang-undang, Akademi Pengajian Islam, Universiti Malaya, 2000.

4. Suwaid Tapah, Perundangan dan Penguatkuasaan Fatwa in Ahmad Hidayat Buang, Fatwa di Malaysia, Jabatan Syariah dan Undang-undang, Akademi Pengajian Islam, Universiti Malaya, Kuala Lumpur, 2004.

5. Suwaid Tapah, "Undang-undang Pentadbiran Fatwa di Malaysia," Jurnal 
Syariah, Jilid 1, Bilangan 2, 1993, pp. 347-56.

6. Mohamed Azam Mohamed Adil, "Penyelarasan Fatwa: Isu, Masalah dan Harapan", Jurnal Hukum, Rabiulakhir 1435H/Februari 2014M, pp. 1-16.

7. Mohamed Azam Mohamed Adil, “ASB, ASN Berlandaskan Maqasid Syariah Pelaburan Diharuskan Bagi Menegakkan Keadilan, Basmi Kemiskinan”, Berita Harian, 4 Mac 2014, p. 33.

8. Mohamed Azam Mohamed Adil, Organisasi dan Pentadbiran Jabatan Mufti in Ahmad Hidayat Buang, Fatwa di Malaysia, Jabatan Syariah dan Undangundang, Akademi Pengajian Islam, Universiti Malaya, Kuala Lumpur, 2004.

9. Mohamed Azam Mohamed Adil, Pengaruh Adat Tempatan dalam Menentukan Fatwa di Malaysia in Ahmad Hidayat Buang, Fatwa di Malaysia, Jabatan Syariah dan Undang-undang, Akademi Pengajian Islam, Universiti Malaya, Kuala Lumpur, 2004.

10. Muhammad Ikhlas Rosele, Luqman Hj Abdullah, Paizah Hj Ismail \& Mohd Anuar Ramli, "Konflik Fatwa di Malaysia: Satu Kajian Awal", Jurnal Fiqh, No.10 (2013), pp. 31-56.

11. Suryani Masnan, Kaedah Pembayaran Zakat Pendapatan Melalui Skim Potongan Gaji Oleh Lembaga Zakat Selangor, Dissertation, Master of Shari'ah, University of Malaya, 2012.

12. Hasnan Kasan, Institusi Fatwa di Malaysia, Penerbit Universiti Kebangsaan Malaysia, Bangi, 2008.

13. Abdul Monir Yaacob \& Wan Roslili Abd Majid (Penyunting), Mufti dan Fatwa di Negara-negara Asean, Institut Kefahaman Islam Malaysia (IKIM), 1998.

14. Abdullah Alwi Hassan, The Administration of Islamic Law in Kelantan, Dewan Bahasa \& Pustaka,Kuala Lumpur, 1996.

15. Farid Sufian Shuaib, Powers and Jurisdiction of Syariah Courts in Malaysia, Malayan Law Journal, 2003.

16. Farid Sufian Shuaib, Tajul Aris Ahmad Bustami \& Mohd Hisham Mohd Kamal, Administration of Islamic Law in Malaysia - Text and Material, Malayan Law Journal, 2001.

17. Federal Constitution of Malaysia.

18. Selangor Islamic Administrative Law Enactment, 2003.

\section{Reported Cases}

1. Hajjah Halimatussaadiah lwn Public Service Commission, Malaysia \& Anor [1992] 1 MLJ 513.

2. Dalip Kaur lwn Pegawai Polis Daerah, Balai Polis Daerah Bukit Mertajam dan lain-lain [1992] 1 MLJ 1.

3. Isa Abdul Rahman and Others $v$ the Penang Islamic Council [1997] 5 Jurnal Syariah (1) 125.

4. Re Dato Bentara Luar (Deceased), Haji Yahya Yusoff \& Others v Hassan Othman \& Others [1981] 2 MLJ 352. 